\title{
Zero Leverage, Media Attention and Cash Dividend Payment - An Empirical Analysis Based on A Share Listed Companies
}

\author{
Zhen-Yi WANG ${ }^{1, a}$, Xi CHEN ${ }^{2, b}$ and Rui-Wen WAN ${ }^{3, c, *}$
}

${ }^{1}$ Yangguang Road in Jiangxia District Wuhan city, School Of Accounting , Wuhan Textile University

${ }^{2}$ Yangguang Road in Jiangxia District Wuhan city, School Of Accounting , Wuhan Textile University

${ }^{3}$ Yangguang Road in Jiangxia District Wuhan city, School Of Accounting , Wuhan Textile University

alwyw@sina.com, 'b2542797837@qq.com , ‘464640129@qq.com

Keywords: Zero leverage, Media attention, Cash dividend

\begin{abstract}
This paper takes the listed companies in Shanghai A-stock market and Shenzhen A-stock market from 2011 to 2016 as research samples, examining the relationship between zero leverage, media attention and cash dividend payment. Through empirical research, this paper reaches the following conclusions: (1) Zero-leverage companies are more willing to pay dividends and these companies have higher payment levels than leveraged companies; (2) For zero leverage companies, The impact of media attention on the willingness to pay dividends in the future and the payment level is even more pronounced.
\end{abstract}

\section{Introduction}

The revised "MM" theory holds that debt can reduce the comprehensive cost of capital and increase the enterprise value due to tax shield effect of interest. In reality, however, many companies have no or few debt in their capital structure. The proportion of zero leverage companies in our country increased from $4.64 \%$ in 2000 to $17.44 \%$ in 2015. This kind of phenomenon that departs from the traditional capital structure theory is called the puzzle of "zero leverage"( Strebulaev \&Yang ,2013).

With the introduction of a series of policies such as "semi-mandatory dividend" by China Securities Regulatory Commission, the cash dividend payment of the company has attracted more attention. Studies have shown that the absence of bank creditors in zero-leverage corporation aggravates the agency conflict between shareholders and management (Zhen Huang 2016). What is the effect on the company's dividend distribution? In addition, the media has become an important external governance mechanism (Peigong Li 2010). Does the media affect the relationship between zero leverage and cash dividend distribution? Under the special system of "de-leverage" in our country, the research on this issue has important practical significance.

This paper takes A-share listed companies as the research sample and 2011-2016 as the test interval, trying to explore the impact of zero leverage on the cash dividend distribution from the theoretical and empirical perspectives .

\section{Theory Analysis and the Research Hypothesis}

\section{Zero Leverage and Cash Dividend Payment}

In terms of company characteristics, dividend-paying companies are generally more profitable and have higher retained surpluses. Zero leverage companies generally have strong profitability, high cash holdings and high ROE. (Strebulaev and Yang 2013). This provides the possibility for companies to distribute dividends. According to agency theory, when companies have more cash flow, management may invest funds in low-return projects in order to gain private interests. The continuous payment of cash dividends by the company will reduce the company's free cash flow and reduce the management's actions that harm the company's overall interests (Wei Xiao, 2010). On the other hand, payment of cash dividends encourages managers to accept external market supervision. Managers will make better investment decisions under the "pressure" of external supervision, which will help reduce the agency problem between shareholders and management 
(Easterbrook, 1984). From the perspective of agency cost, companies will tend to issue cash dividends. To sum up, this paper puts forward the following hypothesis:

Hypothesis 1: Restricting other conditions, zero leverage companies are more willing to pay dividends and have higher payment level than leveraged companies.

\section{The Regulatory Effect of Media Attention}

With the progress of information technology, the media plays an important and positive role in the economic and social development. Firstly, the media, as an intermediary of information, can gather and integrate information from different sources and disseminate them. Media coverage allows information to be rearranged, changing the scope of information distribution and reducing the cost of obtaining information for external stakeholders (Liyi Liu 2014). Secondly, media attention can arouse the attention of regulators. With the increase of the number of reports, the problem of information asymmetry between regulators and companies will be reduced. In order to establish a good image, the government will supervise the establishment of appropriate policies or carrying out direct administrative interventions, promoting the company to pay cash dividends (Xiaorong Li 2015). Media attention can not only affect the external environment in which the company formulates the dividend policy, but also influences the inside of the enterprise through agency mechanism, therefore affecting the dividend policy of the enterprise. The absence of creditors will strengthen the proxy conflict between shareholders and management in zero leverage companies, management have more information than shareholders as internal operators of the company, the intervention of the media make internal and external information to be balanced, reducing the level of information asymmetry of between shareholders and management. At the same time, media attention will make it easy for capital markets to focus on the management for personal gain of listed companies. Based on the free cash flow hypothesis, management uses cash dividends to reduce the free cash flow they can control in order to reduce agency costs. To sum up, this paper puts forward the following hypothesis:

Hypothesis 2: Restricting other conditions, Media attention has a positive regulatory effect on the relationship between zero leverage and cash dividend payments.

\section{Research Design}

\section{Sample Selection and Data Sources}

This research selects the A-share listed companies in Shanghai and Shenzhen stock markets for the period of 2011-2016 as the research sample and carries out the following screening procedures: (1) excluding ST and PT companies (2) Excluding financial listed companies such as bank and insurance. The financial data in this article are collected from the I find Financial Date base. Data processing mainly adopts Excel2003 and Stata11.0 statistic software.

\section{The Selection of Variables and Measurement}

\section{Explained Variable}

The explanatory variable in this paper is the cash dividend payout index. Using the method of Liyi Liu (2014), the payout ratio of cash dividend is taken as the index of cash dividend

\section{Explanatory Variable}

This article draws on Strebulaev and Yang (2013) measurement methods to defined variable. When the sample company's book leverage ratio is zero, zl takes 1,otherwise take 0 .

\section{Regulatory Variables}

Media attention is a regulatory variable for this study. This article takes example by Xiaorong Li ’s(2015) method to use "Baidu search engine" to manually collect. 


\section{Control Variables}

Table1. Variable definitions

\begin{tabular}{|l|l|l|}
\hline symbol & $\begin{array}{l}\text { Control } \\
\text { variables }\end{array}$ & Measurement method \\
\hline SIZE & Firm size & $\begin{array}{l}\text { measured by the logarithm of the company's total } \\
\text { assets. }\end{array}$ \\
\hline ROA & Profitability & $\begin{array}{l}\text { measured by the company's total return on assets at } \\
\text { the end of the period }\end{array}$ \\
\hline FCF & $\begin{array}{l}\text { Free cash } \\
\text { flow }\end{array}$ & $\begin{array}{l}\text { measured by the net free cash flow of the company / } \\
\text { total assets at the end of the period }\end{array}$ \\
\hline Tangibility & $\begin{array}{l}\text { Tangible } \\
\text { assets } \\
\text { proportion }\end{array}$ & $\begin{array}{l}\text { measured by the total tangible assets / total assets at } \\
\text { the ond the period }\end{array}$ \\
\hline CE & $\begin{array}{l}\text { Capital } \\
\text { Expenditure }\end{array}$ & $\begin{array}{l}\text { measured by the total cash paid for the construction of } \\
\text { assed /total assets }\end{array}$ \\
\hline tax & $\begin{array}{l}\text { Tax rate } \\
\text { asets }\end{array}$ & $\begin{array}{l}\text { measured by income tax expense / total assets at the } \\
\text { end of the period }\end{array}$ \\
\hline age & $\begin{array}{l}\text { The } \\
\text { listed years }\end{array}$ & $\begin{array}{l}\text { measured by the number of years since the company } \\
\text { went public }\end{array}$ \\
\hline ind & industry & dummy variable \\
\hline year & dummy variable \\
\hline
\end{tabular}

\section{Model Design}

Build the following basic econometric model and test the proposed research hypotheses:

$$
\begin{aligned}
& \text { payout }=\beta_{0}+\beta_{1} Z L+\beta_{2} C O N T R O L+\varepsilon \\
& \text { payout }=\beta_{0}+\beta_{1} Z L+\beta_{2} \text { CONTROL }+\beta 3 Z L^{*} M E D I A+\varepsilon
\end{aligned}
$$

model (1) examines the relationship between zero leverage and cash dividend payment to verify Hypothesis1. Model (2) examines whether media attention plays a regulatory role between zero leverage and cash dividend payment,

\section{The Empirical Results and Analysis}

Descriptive Statistical Analysis 
Table 2. Descriptive statistical analysis

\begin{tabular}{|l|l|l|l|l|l|}
\hline & $\begin{array}{l}\text { Virtual } \\
\text { value }\end{array}$ & Mean & Maximum & $\begin{array}{l}\text { Minimu } \\
\mathrm{m}\end{array}$ & Std.Deviation \\
\hline Payout & 24634 & 0.1989 & 6.01656 & 0 & 0.7038 \\
\hline Zl & 24634 & 0.1365 & 1 & 0 & 0.3433 \\
\hline Media & 24634 & 59.6595 & 637 & 0 & 59.7127 \\
\hline Size & 24634 & 9.4522 & 11.1523 & 8.216 & 0.5599 \\
\hline Roa & 24634 & 601665 & 29.8727 & -20.744 & 7.1226 \\
\hline Fcf & 24634 & -0.0272 & 0.2788 & -0.676 & 0.1574 \\
\hline $\begin{array}{l}\text { Tangibilit } \\
\text { y }\end{array}$ & 24634 & 43.344 & 92.1024 & -49.747 & 25.479 \\
\hline ce & 24634 & 0.055 & 0.2542 & 0.0001 & 0.0534 \\
\hline tax & 24634 & 0.0098 & 0.0527 & -0.0067 & 0.0101 \\
\hline age & 24634 & 8.8151 & 22 & -1 & 6.1958 \\
\hline
\end{tabular}

Table 2 shows the descriptive statistics analysis results. The maximum of cash dividend payment is 6.0166 , the minimum is 0 , the standard deviation is 0.7038 , and the mean is 0.1989 , which indicates that most of the sample companies have a relatively low cash dividend payout ratio. The maximum of media attention is 637 , the minimum is 0 , and the mean is 59.6595 , indicating that the sample companies are generally less concerned by the media.

\section{Correlation Analysis}

The correlation analysis shows that the zero leverage (ZL) and the is significantly positively correlated cash dividend payment (PAYOUT) at $1 \%$ level $(\beta=0.054, p<0.01)$, indicating that the zero-leveraged company has higher dividend payout, hypothesis $\mathrm{H} 1$ is preliminarily verified. Media attention (MEDIA) and cash dividend payout (PAYOUT) are significantly and positively correlated at $1 \%$ level $(\beta=0.093, \mathrm{p}<0.01)$. Zero leverage (ZL)is significantly positively correlated with $\operatorname{MEDIA}(\beta=0.084, \mathrm{p}<0.01)$ at the $1 \%$ level.

\section{Regression Analysis}

Before the regression analysis, we first conducted a collinearity test on the regression models (1) and (2). The maximum VIF values were 2.02 and 2.89, both of which were less than 3 . This indicated that there was no serious collinearity problem in addition, DW value was 1.552 , indicating that there is no autocorrelation problem. 
Table 3. The results of zero leverage and cash dividend payment regression analysis

\begin{tabular}{|c|c|c|c|c|}
\hline & \multicolumn{2}{|l|}{ model } & \multicolumn{2}{|c|}{ model } \\
\hline ZL & $0.0633^{* * *}$ & 2.89 & $0.0679 * * *$ & 2.93 \\
\hline MEDIA & & & $0.0011 * * *$ & 6.96 \\
\hline ZL*MEDIA & & & $0.0008^{*}$ & 1.74 \\
\hline SIZE & $0.0505^{* * *}$ & 4.31 & $0.0516 * * *$ & 4.38 \\
\hline ROA & $-0.0032 * * *$ & -3.25 & $-0.0032 * * *$ & -3.22 \\
\hline FCF & $0.115^{* * *}$ & 2.79 & $0.116^{* * *}$ & 2.82 \\
\hline TANGIBILITY & $0.0024 * * *$ & 8.71 & $0.0024^{* * *}$ & 8.73 \\
\hline CE & $-0.253^{* *}$ & -2.08 & $-0.254^{* *}$ & -2.10 \\
\hline TAX & $-1.669 * *$ & -2.07 & $-1.727 * *$ & -2.14 \\
\hline AGE & $-0.0105^{* * *}$ & -8.28 & $-0.0105 * * *$ & -8.27 \\
\hline IND & \multicolumn{4}{|c|}{ Controlled } \\
\hline YEAR & \multicolumn{4}{|c|}{ Controlled } \\
\hline AdjustedR $^{2}$ & \multicolumn{2}{|c|}{0.048} & \multicolumn{2}{|c|}{0.050} \\
\hline VIF & \multicolumn{2}{|c|}{2.02} & \multicolumn{2}{|c|}{2.89} \\
\hline
\end{tabular}

The regression results of Table3 show that the zero leverage (ZL) is positively correlated with the cash dividend payment (PAYOUT) at $1 \%$ level in model $(1)(\beta=0.0633, p<0.01)$, indicating zero leverage companies pay a higher level of cash dividend. Assumption 1 is verified. The regression results of the model (2) showed that the zero leverage (ZL) and the cash dividend payment (PAYOUT) are still significantly positively correlated at $1 \%$ level $(\beta=0.0679, \mathrm{p}<0.01)$ when MEDIA was added as the regulated variable. At the same time, cash dividend payment (PAYOUT) is positively correlated with the cross terms of Media attention (MEDIA) and zero leverage (ZL) at $10 \%$ level $(\beta=0.0008, p<0.1)$ The impact of media attention has a positive regulatory effect, which means media attention can enhance the positive impact of zero leverage on cash dividend payments. Therefore, Hypothesis 2 is verified.

\section{Robustness Testing}

This study draws on Qiming Tang's (2016) measure of zero leverage: if interest-bearing liabilities/total assets are zero (less than 5\%), then 1 is used, otherwise 0.Re-examining the relationship between zero leverage and cash dividend payout and the impact of media attention on the relationship between zero leverage and cash dividend payout. The conclusion of empirical analysis remains unchanged .

\section{Research Conclusion and Revelation}

The conclusions are as follows: (1) Zero-leverage and cash dividend payment are significantly and positively correlated, which means zero leverage companies pays higher level of dividend. For the listed companies that choose zero leverage policy, the information asymmetry between shareholders and management can be reduced by distributing cash dividends. (2) Through further tests, we find that media attention can enhance the positive impact of zero leverage on cash dividend payment. Therefore, we should vigorously promote the active role of media attention.

\section{Acknowledgement}

This research was supported by research subject of accounting of accounting society of Hubei province (NBKJ201605). 


\section{References}

[1] Strebulaev I A, and B. Yang. The Mystery of Zero - Leverage Firms [J]. Journal of Financial Economics, 2013, 109 (1): 1-23.

[2] Zhen Huang, Wanli Li, Weiwei Gao. Zero debt companies in the absence of bank creditors will aggravate the conflict between the shareholders and the management of the agency you do [J] .Financial Research, 2016 (02): 147-156.

[3] Peigong Li, Fengshen Yi . The Role of Media in Corporate Governance: Evidence from China [J]. Economic Research, 2010 (4): 14-27

[4] Min Xiao. Cash dividends, internal cash flow and investment efficiency [J] .Financial Research, 2010 (10): 117-134.

[5] Easterbrook, F. Two Angency-cost explanations of dividends [J]. American Economic Review, 1984 (74): 650-659.

[6] Lili Liu, Quan Wen. Media attention and cash dividend policy [J] .Business Research, 2014 (12): 40-47.

[7] Xiaorong Li, Jinhui Luo. Media attention and cash dividend payment [J]. Economic Theory and Business Management, 2015 (09): 68-85. 